\title{
Relationship between Serum $\gamma$-Glutamyl Transpeptidase Fraction Pattern and the Pattern of Food Intake
}

\author{
Masahide IMAKI, Tamotsu MIYOSHI, Kazuoki MATSUMOTO, \\ Manabu KITAKOUJI, Takeo NAKAMURA and Seiki TANADA
}

\begin{abstract}
The effects of the food intake pattern on the activity and fraction pattern of serum $\gamma$-glutamyl transpeptidase $(\gamma$-GTP) were examined in 257 healthy Japanese men.

Applying the technique of factor analysis to the food intake data, the following three factors were extracted. The first factor (F1) : meats, eggs, and vegetables had a highly positive factor loading. The second factor (F2) : wheat had a highly positive factor loading, while rice had a highly negative factor loading. This factor was considered to be a "wheat versus rice factor". The third factor (F3) could not be explained simply in terms of its factor. The scores of the first two factors for the 257 subjects were calculated.

Significantly negative correlations were observed between the percentage of $\mathrm{GT}_{1}$ fraction and the factor score of $\mathrm{F} 1(\mathrm{r}=-0.230, \mathrm{p}<0.01)$, between the percentage of $\mathrm{GT}_{1}$ fraction and the factor score of $\mathrm{F} 2(\mathrm{r}=-0.187, \mathrm{p}<0.01)$. The total serum $\gamma$-GTP activity was not correlated with the factor score. These results suggested that the percentage of $\mathrm{GT}_{1}$ fraction is influenced by the pattern of food intake.
\end{abstract}

(1) serum $\gamma$-GTP activity (2) serum GT fraction (3) pattern of food intake (4) multivariate analysis

\section{Introduction}

Health screening for alcoholism occupies an important place in rural medicine, and there have been many reported on the alcohol intake in rural inhabitants ${ }^{1 \sim 3)}$. The activity of serum $\gamma$-GTP has been widely used as a diagnostic tool for alcoholic liver diseases. However, there have been no published reports on the correlation between its activity and fraction pattern with the intake of nutrients in healthy people. In previous studies ${ }^{4 \sim 5)}$, the percentage of $\mathrm{GT}_{1}$ fraction showed a close correlation with the intake of carbohydrates ${ }^{4}$, proteins and vitamin $\mathrm{C}^{5}$. Then, we examined the relation between both activity and fraction pattern of serum $\gamma$-GTP to the pattern of food intake in healthy young Japanese men applying the statistical technique of multivar- iate analysis which is widely used in the field of public health.

\section{Methods}

\section{1) Subject}

The subjects studied were 257 healthy Japanese men. They were university students, and followed a normal daily routine. They were healthy as judged from their detailed medical histories, physical examinations, urinalyses and hematological and serum biochemical analyses. The physical characteristics of the subjects are given in Table 1. Their conditions were as follows: a) None had any disease which required hospital treatment. b) None had any disease of the hepatobiliary system. c) None had chronic diseases of the heart or diabetes mellitus. d) Liver function tests were within the

* Department of Public Health, School of Medicine, The University of Tokushima 
Table 1. Characteristics of subjects

\begin{tabular}{|c|c|c|c|c|}
\hline Items & Mean & S.D. & Max. & Min. \\
\hline Age & 23.1 & 3.4 & 28 & 21 \\
\hline Height $(\mathrm{cm})$ & 170.7 & 5.4 & 190.0 & 153.0 \\
\hline Weight （kg） & 63.0 & 8.0 & 85.0 & 49.0 \\
\hline Broca index & 89.2 & 9.9 & 118.2 & 68.3 \\
\hline
\end{tabular}

Number of subjects : 257 men

Broca index : [Weight / (Height -100) $] \times 100$

normal range. e) None had hyperlipidemia. f) None drank habitually.

2) Diets

The subjects recorded their food intake after each meal or snack. All food eaten by the subjects in a 2-day period before the test was weighed, and the intake of each of 15 food was calculated, using the standard tables of food composition in Japan (4th revised edition $\left.{ }^{6}\right)$.

3) Blood samples

Venous blood samples were obtained from subjects after they underwent overnight fasting for at least 12 hours. The serum was separated and stored at $4^{\circ} \mathrm{C}$ for analysis. Serum $\gamma$-GTP activity and the percentage of the $\gamma$-GTP fraction were measured on the day that blood was taken. Serum $\gamma$-GTP activity $^{7)}$ was determined with a $\gamma$-GTP Test Kit (Wako Pure Chemical Industries). Serum $\gamma$-GTP fractions $^{5)}$ were separated by electrophoresis on agarose film. Two $\gamma$-GTP fractions were obtained, one with mobility at a level between those of albu$\min$ and $\alpha(1)$-globulin $\left(\mathrm{GT}_{1}\right)$, and the other with the same mobility as that of the lowest part of $\alpha(2)$ -globulin $\left(\mathrm{GT}_{2}\right)$. The serum $\gamma$-GTP activity and percentage of the $\gamma$-GTP fraction were measured three times for each sample and the mean values for each sample were calculated. The pooled serum prepared in our department was used as the control. 4) Analyses

Data were processed by a NEC PC9801VX computer. Factor analysis, a multivariate analysis, was applied to intakes of 15 group of foods in all subjects. The 15 groups of foods examined are listed in Table 2. Factor scores were calculated for the 4855 (257X15) data with factor loadings used for weight.

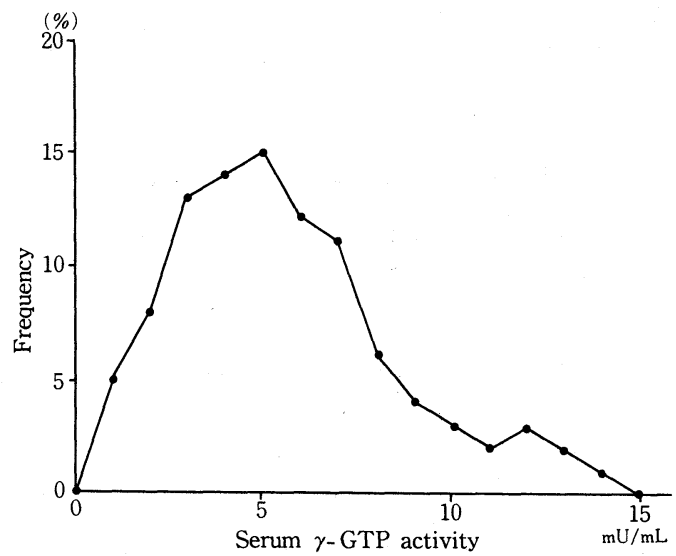

Fig. 1. Distribution of serum $\gamma$-GTP activity

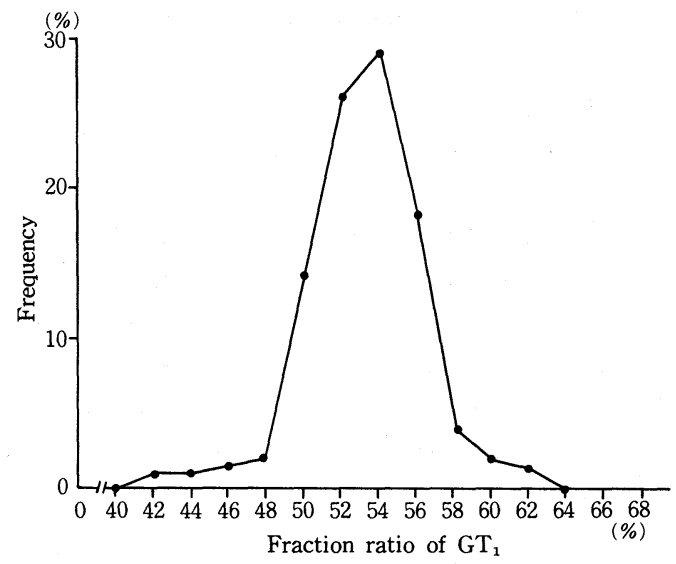

Fig. 2. Distribution of fraction ratio of $G T_{1}$

\section{Results}

1) Distribution of serum $\gamma$-GTP activity and fraction pattern

Fig. 1 show the distribution of serum $\gamma$-GTP activity in the 257 subjects. Their values leaned foward a higher concentration with a peak at $5 \mathrm{mU} /$ $\mathrm{mL}$. The mean serum $\gamma$-GTP activity was $6.1 \pm 4.3$ $\mathrm{mU} / \mathrm{mL} \quad(0.8 \sim 14.4 \mathrm{mU} / \mathrm{ml})$. The distribution of serum $\gamma$-GTP fraction pattern in the 257 subjects as shown in Fig. 2. The mean percentage of $\gamma-\mathrm{GT}_{1}$ fraction was $54.4 \pm 2.7 \%$ ( $43.6 \sim 63.5 \%)$.

2) Food intakes of subjects

The means and standard deviations of food intakes of the subjects are shown in Table 2. All the subjects were well nourished, and apparently in 
Table 2. Food intake

\begin{tabular}{lrrrr}
\hline Items & Mean & S.D. & Max. & Min. \\
\hline 1. Rice & 253.2 & 79.4 & 510.1 & 70.0 \\
2. Wheat & 107.2 & 64.9 & 440.1 & 11.3 \\
3. Potatoes & 45.0 & 46.8 & 170.0 & 0.0 \\
4. Sugar & 8.4 & 9.8 & 84.0 & 1.0 \\
5. Nuts and Seeds & 1.8 & 10.5 & 74.3 & 0.0 \\
6. Fats and Oils & 23.5 & 13.4 & 54.1 & 5.0 \\
7. Pulses & 72.3 & 84.1 & 301.0 & 0.0 \\
8. Fishes & 62.2 & 59.6 & 240.5 & 0.0 \\
9. Meats & 128.5 & 75.4 & 302.0 & 0.0 \\
10. Eggs & 62.8 & 62.8 & 180.0 & 0.0 \\
11. Milks & 156.1 & 147.3 & 740.0 & 0.0 \\
12. Vegetables & 211.1 & 108.5 & 676.2 & 41.2 \\
13. Fruits & 60.8 & 94.5 & 540.0 & 0.0 \\
14. Algae & 2.3 & 7.0 & 17.0 & 0.0 \\
15. Confectioneries & 27.4 & 45.5 & 220.0 & 0.0 \\
\hline
\end{tabular}

good health.

3) Statistical analysis

Applying the technique of factor analysis to the food intake data, we extracted three factors. The factor loadings of 15 food groups are shown in Table 3. The contribution ratios of the first, and second factors were $44.7 \%$, and $22.5 \%$, respectively.

The first factor (F1) : meats, eggs, and vegetables had highly positive factor loadings. The second factor (F2): wheat had a highly positive factor loading, while rice had a highly negative factor loading. This factor was considered to be a "wheat versus rice factor". The third factor (F3) could not be explained simply in terms of its factor. The scores of the two factors for the 257 subjects were calculated. Table 4 shows the correlation coefficient between serum $\gamma$-GTP activity, percentage of $\mathrm{GT}_{1}$ fraction and factor scores. Significantly negative correlations were observed between the percentage of $\mathrm{GT}_{1}$ fraction and factor scores of $\mathrm{F} 1(\mathrm{r}=-0.230$ $\mathrm{p}<0.01$ ), between the percentage of $\mathrm{GT}_{1}$ fraction and factor scores of $\mathrm{F} 2(\mathrm{r}=-0.187, \mathrm{p}<0.01)$. The serum total $\gamma$-GTP activity was not correlated with factor scores.
Table 3. Factor loadings

\begin{tabular}{lrrrr}
\hline \multirow{2}{*}{ Items } & \multicolumn{3}{c}{ Factor loadings } & Commu- \\
& \multicolumn{1}{c}{ F1 } & \multicolumn{1}{c}{ F2 } & \multicolumn{1}{c}{ F3 } & nality \\
\hline 1. Rice & -0.062 & -0.770 & 0.264 & 0.528 \\
2. Wheat & 0.057 & 0.808 & 0.083 & 0.527 \\
3. Potatoes & -0.066 & -0.101 & 0.406 & 0.191 \\
4. Sugar & -0.047 & 0.064 & 0.312 & 0.104 \\
5. Nuts and Seeds & -0.054 & -0.051 & 0.080 & 0.065 \\
6. Fats and Oils & 0.191 & -0.038 & 0.282 & 0.130 \\
7. Pulses & -0.172 & -0.313 & 0.235 & 0.213 \\
8. Fishes & 0.225 & -0.028 & -0.143 & 0.357 \\
9. Meats & 0.753 & 0.093 & -0.106 & 0.591 \\
10. Eggs & 0.711 & 0.155 & -0.103 & 0.603 \\
11. Milks & 0.247 & 0.679 & -0.045 & 0.582 \\
12. Vegetables & 0.741 & -0.049 & 0.079 & 0.425 \\
13. Fruits & -0.083 & 0.178 & 0.111 & 0.121 \\
14. Algae & 0.283 & 0.046 & 0.018 & 0.084 \\
15. Confectioneries & 0.047 & -0.130 & 0.303 & 0.282 \\
\hline Eigen value & 2.397 & 1.207 & 0.763 & \\
\hline Proportion $(\%)$ & 44.7 & 22.5 & 14.2 & \\
\hline
\end{tabular}

F1: Factor 1, F2: Factor 2, F3: Factor 3

Table 4. The correlation coefficient between serum total $\gamma$-GTP activity, percentage of $\mathrm{GT}_{1}$ fraction and factor scores

\begin{tabular}{lcc}
\hline Item & Factor 1 & Factor 2 \\
\hline$\gamma-\mathrm{GTP}(\mathrm{T})$ & 0.101 & 0.088 \\
$\mathrm{GT}_{1}$ & $-0.230^{* *}$ & $-0.187^{* *}$ \\
\hline
\end{tabular}

$$
\text { ** }: \mathrm{P}<0.01
$$

$\gamma$-GTP(T): Total serum $\gamma$-GTP activity

$\mathrm{GT}_{1}$ : Percentage of $\mathrm{GT}_{1}$ fraction

\section{Discussion}

Multiphasic health screening for chronic diseases occupies an important place in periodic examinations. Measurements of $\gamma$-GTP in serum are frequently used as an indicator of hepatobiliary diseases, including alcohol-or drug-induced liver damage.

Previously ${ }^{9}$, we reported the relations between its activity and fraction pattern and the intakes of nutrients. In the present study, we investigated the effect of the pattern of food intake on serum $\gamma$-GTP activity and fraction in healthy young men. When diets of groups are examined, the intakes of individ- 
ual food items or nutrient intakes are not independent of each other but show synergistic or antagonistic relations with other food items or nutrient intakes. Thus, the relation constitutes what is generally called a pattern of food intake ${ }^{10}$.

We used multivariate analysis (factor analysis) to analyze the data on food intake of the subjects. According to the method, common factor of $f_{1}, f_{2}$, . $\ldots$ and $\mathrm{f}_{\mathrm{m}}$ are linear components given as follows: $x_{1}=a_{11} f_{1}+a_{12} f_{2}+\ldots+a_{1 \mathrm{~m}} f_{\mathrm{m}}+\varepsilon_{1}$ $x_{2}=a_{21} f_{1}+a_{22} f_{2}+\ldots+a_{2 \mathrm{~m}} f_{\mathrm{m}}+\varepsilon_{2}$ $\ldots \ldots \ldots \ldots$ $x_{\mathrm{p}}=a_{\mathrm{p} 1} f_{1}+a_{\mathrm{p} 2} f_{2}+\ldots+a_{\mathrm{pm}} f_{\mathrm{m}}+\varepsilon_{\mathrm{p}}$ $a_{\mathrm{pm}}$ is the factor loading. Thus the factor analysis might be said to summarize the information contained in the total number of variables into a smaller number of independent factors, which are linear functions of the original variable. This method allowed analysis of the patterns of food intake of the subjects. The results obtained were as follows : the first factor might be interpreted as a factor determining the relative degree of importance of meats, eggs and vegetables in the diet. In this study, significantly negative correlations were observed between the percentage of $\mathrm{GT}_{1}$ fraction and the factor score of $F_{1}$ : in other words, although the percentage of $\mathrm{GT}_{1}$ fraction remained within the normal range, they tended to increase with the decrease in intake of meats, eggs and vegetables.

The second factor is supposed to be a factor indicating degrees of importance of wheat and rice ; that is, a factor related to the nature of the main constituent of the food. A significantly negative correlation was observed between the percentage of $\mathrm{GT}_{1}$ fraction and the factor score of $\mathrm{F} 2$ : the percentage of $\mathrm{GT}_{1}$ fraction tended to increase with the decrease in wheat intake and increase in rice intake. In other words, the percentage of $\mathrm{GT}_{1}$ fraction was high in subjects who ate traditional Japanese food with rice as the main constituent. With respect to the relationship between the percentage of $\mathrm{GT}_{1}$ fraction and nutrient intakes, Antener et al.. ${ }^{11 \sim 12)}$ observed that in patients with malnutrition, the percentage of $\mathrm{GT}_{1}$ fraction is lowered by improvement of the nutritional state such as by increased intakes of an energy source, protein, vitamins and minerals. We observed that the percentage of $\mathrm{GT}_{1}$ fraction increased significantly in eight healthy young volunteers who received a low protein diet for 21 days, and in four healthy young volunteers who received a high carbohydrate ${ }^{1)}$ diet for 21 days. We also observed that after 10 days of oral administration with 1 and $10 \mathrm{~g} /$ day of vitamin $\mathrm{C}$ to six normal subjects, their percentage of $\mathrm{GT}_{1}$ fraction was lower than that before administration ${ }^{5}$.

The mechanism of increase in the percentage of the $\mathrm{GT}_{1}$ fraction is unknown. However, Koike et $\mathrm{al}^{13)}$ reported that a low protein intake, low vitamin $\mathrm{C}$ intake and imbalanced diet caused metabolic stress. The data in these papers also suggested that the percentage of $\mathrm{GT}_{1}$ fraction increased in certain individuals in response to metabolic stress induced by an imbalanced pattern of food intake, and that its fraction passed from the liver into the blood stream due to slight fatty degeneration of the liver. The present study indicated that the levels tended to increase with high intake of meats, eggs and vegetables, and that, with intake of modern food sources with wheat as the main constisuent, the levels of the percentage of $\mathrm{GT}_{1}$ fraction were low. With respect to the relations of the serum $\gamma$-GTP activity and nutrient intake, Antener et $\mathrm{al}^{11 \sim 12)}$ reported that patients with malnutrition have abnormally higher levels of serum $\gamma$-GTP and that the level is normalized when the nutritional state is improved. Fujisawa et $\mathrm{al}^{14)}$ reported that in healthy subjects the daily variation in serum $\gamma$-GTP activity is small and is not affected by daily meals. In the present study, we found that the pattern of food intake did not affect serum $\gamma$-GTP activity.

In general, the nutritional status of a subject depends on his social, economic, personal and family background. Our results suggested that the low $\mathrm{GT}_{1}$ subjects had a good food intake pattern which prevents chronic diseases from occurring. It is worthy of attention how the food intake pattern of rural people will change in future from the viewpoint of the possibility of change which will be recognized in the national health status. Therefore, we think that measurement of $\mathrm{GT}_{1}$ is important in rural medicine. 


\section{References}

1) Imura, T., Kuriwaka, R., Nisimura, N., Matsuura, H., Kashihara, S., Kageyama, T. and Bando, A.: Study on relationship between alcohol drinking and health (2), Jpn. J. Rural Med., 37 (3), 254-255, 1988 (in Japanese).

2 ) Bando, A : Study on relationship between drinking habitually and health. Report of studies commissioned by the Ministry of Health and Welfare, 1-114, 1988.

3) Morimoto, T. et al. : Relation between drinking and liver function in case of a thorough physical examination. Jan. J. Rural Med., 37 (1), 38-41, 1988.

4) Yoshimura, T. et al: EFFECT OF HIGH CARBOHYDRATE DIET ON SERUM $\gamma$-GLUTAMYL TRANSPEPTIDASE FRACTION PATTERN IN JAPANESE YOUNG MEN, Acta Biol. Hung., 235-241, 1986.

5 ) Yoshimura, T., Miyoshi, T., Imaki, M. and Tamura, T.: Relationship between serum $\gamma$-GTP and serum vitamin C. Jpn. J. Hyg., 40, 774-780 (in Japanese).

6) The Science and Technology Agency: Japanese Food Composition Table (4th ed.), The Finance Ministry Printing Office, Tokyo, 1983.

7) Orlowski, M. and Szewczuk, A.: Determination of $\gamma$
-Glutamyl transpeptidase activity in human serum and urine. Clin. Chim. Acta. 7, 755-760, 1962.

8 ) Igari, J. : $\gamma$-GTP isoenzyme. Medical Technology, 7, 1317 $-1321,1979$.

9) Yoshimura, T., Miyoshi, T. and Imaki, M.: Relationship between serum $\gamma$-GTP and nutrient intakes. Jpn. J. Hyg., 39, 899-904, 1985.

10) Toyokawa, H., Ichikawa, M., Matsumura, Y., Marui, E., Kaneko, S. and Miyake, Y.: Trend of food consumption pattern reflected upon economic growth. Jpn. J. Health Hum. Ecol., 47, 138-147, 1981.

11) Antener, I., Give, F., Mauron, J. and Verwilighen, A. M. : Measurement of serum iso-enzymes of $\gamma$-glutamyl transpeptidase in malnutrition. Acta Paediatr BELG., 33, 9-15, 1980.

12) Antener, I., Verwilighen, A. M., Geert, C. V. and Mauron, J. : Biochemical study of malnutritionsituation before treatment. Acta Tropica., 34, 331-354, 1977.

13) Koike, G., Fulukawa, H., Fukuda, H. and Hosoya, K. : Nutirtion, Asakurashoten, Tokyo, 1973.

14) Fujisawa, J. and Kitamura. T.: Serum $\gamma$-GTP isoenzyme. Jpn. J. Clin. Path., 43, 42-53, 1981 (in Japanese).

\section{血清 $\boldsymbol{\gamma}$-Glutamyl Transpeptidase 分画と 食物摂取パターンとの関連性について \\ 今木雅英, 三好保, 松本和興, 北小路学, 中村武夫, 棚田成紀}

血清 $\gamma$-GTP 分画と食物摂取パターンの関連性について, 健康な日本人青年257名を対象に以下の 疫学的調査を実施した。対象者の食物摂取データを用いて, 因子分析法により食物摂取パターンの 三つの因子を抽出した。第 1 因子は, 肉類, 卵類, 野菜類に正の高い因子負荷量があり肉類, 卵類, 野菜類を多食するパターンである。第 2 因子は小麦類が正の高い因子負荷量, 米類は負の高い因子 負荷量を示し，「パン食対米食」因子である。つまり負の因子得点の対象は米食中心の食パターンで ある。第 3 因子は十分に説明でさなかった。

これらの因子と血清 $\gamma$-GTP 活性值との関連性を解析すると, 統計的に有意な負の相関が $\mathrm{GT}_{1}$ 分 画比と第 1 因子 $(\mathrm{r}=-0.230, \mathrm{p}<0.01)$, 第 2 因子 $(\mathrm{r}=-0.187, \mathrm{p}<0.01)$ に認められた。しかし 総血清 $\gamma$-GTP 活性值とは有意な関係は認められなかった。以上の結果より, 食物摂取パターンが $\gamma$ -GTP 分画比に影響を与えていることが疫学的に認められた。

\footnotetext{
* 徳島大学医学部公衆衛生学講座

（受付：1989年 5 月 22 日）
} 